\title{
A Novel Method for Multiple Criteria Analysis: Grey Additive Ratio Assessment (ARAS-G) Method
}

\author{
Zenonas TURSKIS, Edmundas Kazimieras ZAVADSKAS \\ Vilnius Gediminas Technical University \\ Sauletekio al. 11, LT-10223 Vilnius, Lithuania \\ e-mail:zenonas.turskis@vgtu.lt,edmundas.zavadskas@adm.vgtu.lt
}

Received: February 2010; accepted: September 2010

\begin{abstract}
The paper presents the process of the selection of a potential supplier, which have to be the most appropriate to stakeholders. The selection is based on a set of criteria: Delivery Price, Financial Position, Production Specifications, Standards and Relevant Certificates, Commercial Strength, and the Performance of supplier, etc. The criteria for evaluation and their importance are selected by taking into consideration the interests and goals of the stakeholders. The solution of problem was made by applying a new Additive Ratio ASsessment (ARAS) method with the grey criteria scores - ARAS-G method. The proposed technique could be applied to substantiate the selection of effective alternative of sustainable development, impact on environment, structures, technologies, investments, etc.
\end{abstract}

Keywords: operation research, decision making, grey relations, multiple criteria, MCDM, alternative, supplier, selection, evaluation, weights, Additive Ratio Assessment, ARAS, ARAS-G.

\section{Introduction}

The Roman philosopher Seneca said "Nothing is certain except the past." Future is uncertain. All new ideas and possible variants of decisions in real world must be compared according to a set of multiple conflicting criteria (Turskis et al., 2009). The problem of decision-maker consists of evaluating a finite set of alternatives in order to find the best one, to rank them from the best to the worst, to group them into predefined homogeneous classes, or to describe how well each alternative meets all the criteria simultaneously.

The multiple criteria decision making is a model that allows the analysis of several preference criteria simultaneously. Techniques and planning methods and decision making methods develop dynamically (Kapliński, 2008; Ginevicius et al., 2008; Kalibatas and Turskis, 2008; Sivilevičius et al., 2008; Turskis, 2008; Zavadskas et al., 2008a, 2009a). MCDM is one of the most widely used decision methodologies in the sciences, business, and government worlds (Zavadskas et al., 2008b).

In an MCDM approach, first it is necessary to define the problem clearly, and then identify realistic alternatives. It is important to define the actors involved in the decision 
making, select the evaluation criteria, and evaluate each alternative according to the set of criteria. Next, an MCDM method is selected to aggregate the performance of each alternative.

Different types of MCDM methods can be used for complex problem solution:

- Methods based on quantitative measurements. The methods based on multiple criteria utility theory may be referred to this group (TOPSIS - Technique for Order Preference by Similarity to Ideal Solution (Hwang and Yoon, 1981; Zavadskas et al., 2010b), SAW - Simple Additive Weighting (MacCrimon, 1968; Medineckiene et al., 2010), LINMAP - Linear Programming Techniques for Multidimensional Analysis of Preference (Srinivasan and Shocker, 1973), COPRAS - Complex Proportional Assessment (Zavadskas and Kaklauskas, 1996), its modification COPRAS-G (Complex Proportional ASsessment method with Grey interval numbers; Zavadskas et al., 2008c, 2008d, 2009b), and ARAS (Additive Ratio Assessment) method (Zavadskas and Turskis, 2010).

- Methods based on qualitative initial measurements. These include two widely known groups of methods, i.e., Analytic Hierarchy Methods (AHP; Saaty, 1977) and fuzzy set theory methods (Zimmerman, 2000).

- Comparative preference methods based on pair-wise comparison of alternatives. This group comprises the modifications of the ELECTRE (Roy 1990), PROMETHEE (Brans et al., 1984), UTA (Jacquet-Lagreze and Siskos, 1982), MUSA Grigoroudis and Siskos, 2002), AKUTA (Bous et al., 2010), TACTIC (Vansnick, 1986), ORESTE (Roubens, 1982) and other methods.

- Methods based on qualitative measurements not converted to quantitative variables. This group includes methods of verbal decision-making analysis (Berkeley et al., 1991) and uses qualitative data for decision environments involving high levels of uncertainty.

An alternative in multiple criteria evaluation is usually described by quantitative and qualitative criteria. The criteria have different units of measurement (Kersuliene et al., 2010). Normalization aims at obtaining comparable scales of the criteria values. Different techniques of criteria value normalization are used. The impact of the decision-matrix normalization methods on the decision results has been investigated by many authors (Ginevičius, 2008; Noarul Haq and Kannan, 2007; Zavadskas and Turskis, 2008).

\section{Grey Number}

Li et al. (2007) argued that since the decision makers such as preferences on alternatives or on the criteria of suppliers are often uncertain, supplier selection becomes more difficult. Grey theory is one of the methods used to study uncertainty, being superior in the mathematical analysis of systems with uncertain information. The advantage of grey theory over fuzzy sets theory is that grey theory can deal flexibly with the fuzziness situation. Alternative's selection can be viewed as a grey system process. We may use grey theory to resolve it. The ratings of criteria are described by linguistic variables that can be expressed in grey numbers. 
Grey theory, proposed and originally developed by Deng (1982), is an effective mathematical means to:

- deal with problems described by incomplete information;

- to avoid the inherent defects o conventional, statistical methods;

- and advantage is to use a limited amount of data to estimate the behaviour of an uncertain system when the data are discrete and the information is incomplete $(\mathrm{Wu}$, 2006.)

Due to presence of incomplete information and uncertain relations it is very difficult to use ordinary methods.

White number, grey number and black number are three classifications to distinguish the uncertainty level of information (Chen and Tzeng, 2004). Let

$$
\otimes x=[\alpha, \gamma]=\{x \mid \alpha \leqslant x \leqslant \gamma, \alpha \text { and } x \in R\}
$$

Then, $\otimes x$ which has two real numbers $\alpha$ (the lower limit of $\otimes x$ ) and $\gamma$ (the upper limit of $\otimes x)$ is defined as follows:

- if $\alpha \rightarrow-\infty$ and $\gamma \rightarrow \infty$, then $\otimes x$ is called the black number which means without any meaningful information;

- else if $\alpha=\gamma$, then $\otimes x$ is called the white number which means with complete information;

- otherwise, $\otimes x=[\alpha, \gamma]$ is called the grey number which means insufficient and uncertain information.

Nevertheless, the obtained information from real world is always uncertain or incomplete. Hence, extending the applications from white numbers (crisp values) to grey numbers is necessary for real-world applications. The basic definitions and operations of grey number are described as follows.

Let a grey number is defined to be grey number defined by two parameters $(\alpha, \gamma)$. Let ,,$+- \times$ and $\div$ denote the operations of addition, substraction, multiplication and division espectively. The basic operations of grey numbers $\otimes n_{1}$ and $\otimes n_{2}$ are defined as follows:

$$
\begin{aligned}
& \otimes n_{1}+\otimes n_{2}=\left(n_{1 \alpha}+n_{2 \alpha}, n_{1 \gamma}+n_{2 \gamma}\right) \quad \text { addition, } \\
& \otimes n-\otimes n=\left(n_{1 \alpha}-n_{2 \gamma}, n_{1 \gamma}-n_{2 \alpha}\right) \quad \text { substraction, } \\
& \otimes n_{1} \times \otimes n_{2}=\left(n_{1 \alpha} \times n_{2 \alpha}, n_{1 \gamma} \times n_{2 \gamma}\right) \quad \text { multiplication, } \\
& \otimes n_{1} \div \otimes n_{2}=\left(\frac{n_{1 \alpha}}{n_{2 \gamma}}, \frac{n_{1 \gamma}}{n_{2 \alpha}}\right) \quad \text { division, } \\
& k \times\left(\otimes n_{1}\right)=\left(k n_{1 \alpha}, k n_{1 \gamma}\right) \quad \text { number product of grey numbers } \\
& \left(\otimes n_{1}\right)^{-1}=\left(\frac{1}{n_{1 \gamma}}, \frac{1}{n_{1 \alpha}}\right) .
\end{aligned}
$$




\section{The Proposed Grey Multiple Criteria Decision Making Model: An Additive Ratio Assessment Method with Grey Values (ARAS-G)}

ARAS method (Zavadskas and Turskis, 2010, Zavadskas et al., 2010a; Tupenaite et al., 2010) is based on the argument that phenomena of complicated world could to be understood by using simple relative comparisons. It is argued that the ratio of the sum of normalized and weighted values of criteria, which describe alternative under consideration, to the sum of the values of normalized and weighted criteria, which describes the optimal alternative, is degree of optimality, which is reached by the alternative under comparison.

According to the ARAS method a utility function value determining the complex relative efficiency of a reasonable alternative is directly proportional to the relative effect of values and weights of the main criteria considered in a project.

The first stage is grey decision-making matrix (GDMM) forming. In the GMCDM of the discrete optimization problem any problem to be solved is represented by the following DMM of preferences for $m$ reasonable alternatives (rows) rated on $n$ criteria (columns):

$$
\tilde{X}=\left[\begin{array}{ccccc}
\otimes x_{01} & \cdots & \otimes x_{0 j} & \cdots & \otimes x_{0 n} \\
\vdots & \ddots & \vdots & \ddots & \vdots \\
\otimes x_{i 1} & \cdots & \otimes x_{i j} & \cdots & \otimes x_{i n} \\
\vdots & \ddots & \vdots & \ddots & \vdots \\
\otimes x_{m 1} & \cdots & \otimes x_{m j} & \cdots & \otimes x_{m n}
\end{array}\right] ; \quad i=\overline{0, m} ; j=\overline{1, n}
$$

where $m$ - number of alternatives, $n$ - number of criteria describing each alternative, $\otimes x_{i j}$ - grey value representing the performance value of the $i$ alternative in terms of the $j$ criterion, $\otimes x_{0 j}$ - optimal value of $j$ criterion.

If optimal value of $j$ criterion is unknown, then

$$
\begin{aligned}
& \otimes x_{0 j}=\max _{i} \otimes x_{i j}, \quad \text { if } \max _{i} \otimes x_{i j} \text { is preferable, and } \\
& \otimes x_{0 j}=\min _{i} \otimes x_{i j}^{*}, \quad \text { if } \min _{i} \otimes x_{i j}^{*} \text { is preferable. }
\end{aligned}
$$

Usually, the performance values $\otimes x_{i j}$ and the criteria weights $\otimes w_{j}$ are viewed as the entries of a DMM. The system of criteria as well as the values and initial weights of criteria are determined by experts. The information can be corrected by the interested parties by taking into account their goals and opportunities.

Then the determination of the priorities of alternatives is carried out in several stages.

Usually, the criteria have different dimensions. The purpose of the next stage is to receive dimensionless weighted values from the comparative criteria. In order to avoid the difficulties caused by different dimensions of the criteria, the ratio to the optimal value is used. There are various theories describing the ratio to the optimal value. However, 
the values are mapped either on the interval $[0 ; 1]$ or the interval $[0 ; \infty)$ by applying the normalization of a DMM.

In the second stage the initial values of all the criteria are normalized - defining values $\otimes \bar{x}_{i j}$ of normalised decision-making matrix $\otimes \bar{X}$ :

$$
\otimes \bar{X}=\left[\begin{array}{ccccc}
\otimes \bar{x}_{01} & \cdots & \otimes \bar{x}_{0 j} & \cdots & \otimes \bar{x}_{0 n} \\
\vdots & \ddots & \vdots & \ddots & \vdots \\
\otimes \bar{x}_{i 1} & \cdots & \otimes \bar{x}_{i j} & \cdots & \otimes \bar{x}_{i n} \\
\vdots & \ddots & \vdots & \ddots & \vdots \\
\otimes \bar{x}_{m 1} & \cdots & \otimes \bar{x}_{m j} & \cdots & \otimes \bar{x}_{m n}
\end{array}\right] ; \quad i=\overline{0, m} ; j=\overline{1, n}
$$

The criteria, whose preferable values are maxima, are normalized as follows:

$$
\otimes \bar{x}_{i j}=\frac{\oplus x_{i j}}{\sum_{i=0}^{m} \otimes x_{i j}} .
$$

The criteria, whose preferable values are minima, are normalized by applying twostage procedure:

$$
\otimes x_{i j}=\frac{1}{\otimes x_{i j}^{*}} ; \quad \otimes \bar{x}_{i j}=\frac{\otimes x_{i j}}{\sum_{i=0}^{m} \otimes x_{i j}} .
$$

When the dimensionless values of the criteria are known, all the criteria, originally having different dimensions, can be compared.

The third stage is defining normalized-weighted matrix $-\otimes \hat{X}$. It is possible to evaluate the criteria with weights $0<\otimes w_{j}<1$. Only well-founded weights should be used because weights are always subjective and influence the solution. The values of weight $\otimes w_{j}$ are usually determined by the expert evaluation method. The sum of weights $w_{j}$ would be limited as follows:

$$
\begin{aligned}
& \sum_{j=1}^{n} w_{j}=1, \\
& \otimes \hat{X}=\left[\begin{array}{ccccc}
\otimes \hat{x}_{01} & \cdots & \otimes \hat{x}_{0 j} & \cdots & \otimes \hat{x}_{0 n} \\
\vdots & \ddots & \vdots & \ddots & \vdots \\
\otimes \hat{x}_{i 1} & \cdots & \otimes \hat{x}_{i j} & \cdots & \otimes \hat{x}_{i n} \\
\vdots & \ddots & \vdots & \ddots & \vdots \\
\otimes \hat{x}_{m 1} & \cdots & \otimes \hat{x}_{m j} & \cdots & \otimes \hat{x}_{m n}
\end{array}\right] ; \quad i=\overline{0, m} ; j=\overline{1, n} .
\end{aligned}
$$

Normalized-weighted values of all the criteria are calculated as follows: 


$$
\otimes \hat{x}_{i j}=\otimes \bar{x}_{i j} \times \otimes w_{j} ; \quad i=\overline{0, m}
$$

where $w_{j}$ is the weight (importance) of the $j$ criterion and $\bar{x}_{i j}$ is the normalized rating of the $j$ criterion.

The following task is determining values of optimality function:

$$
\otimes S_{i}=\sum_{j=1}^{n} \otimes \hat{x}_{i j} ; \quad i=\overline{0, m}
$$

where $\otimes S_{i}$ is the value of optimality function of $i$ alternative.

The biggest value is the best, and the least one is the worst. Taking into account the calculation process, the optimality function $\otimes S_{i}$ has a direct and proportional relationship with the values $\otimes x_{i j}$ and weights $\otimes w_{j}$ of the investigated criteria and their relative influence on the final result. Therefore, the greater the value of the optimality function $\otimes S_{i}$, the more effective the alternative. The priorities of alternatives can be determined according to the value $\otimes S_{i}$. Consequently, it is convenient to evaluate and rank decision alternatives when this method is used.

The result of grey decision making for each alternative is grey number $\otimes S_{i}$. There are several methods for transforming grey values to crisp values. The centre-of-area is the most practically and simple to apply:

$$
S_{i}=\frac{1}{2}\left(S_{i \alpha}+S_{i \gamma}\right)
$$

The degree of the alternative utility is determined by a comparison of the variant, which is analysed, with the ideally best one $S_{0}$. The equation used for the calculation of the utility degree $K_{i}$ of an alternative $A_{i}$ is given below:

$$
K_{i}=\frac{S_{i}}{S_{0}} ; \quad i=\overline{0, m}
$$

where $S_{i}$ and $S_{0}$ are the optimality criterion values, obtained from (16).

It is clear, that the calculated values $K_{i}$ are in the interval $[0 ; 1]$ and can be ordered in an increasing sequence, which is the wanted order of precedence. The complex relative efficiency of the reasonable alternative can be determined according to the utility function values.

\section{Case Study}

The government-linked company decided to invest a sum of money for a new municipal solid waste disposal system. The percentage of sales revenues spent on purchased materials typically ranges between $50-90 \%$. One of the most crucial is the selection of the right 
supplier. The right supplier provides the right quality of materials, on time, at the right price, and the right level of service.

Selecting and evaluating the right suppliers is imperative for an organization's global marketplace competitiveness. The selection of an optimal material for an engineering design from among two or more alternative materials on the basis of two or more criteria is a multiple criteria decision-making problem. Supplier selection process represents a complex problem and thus a multiple criteria decision making (MCDM) problem.

When selecting materials for engineering designs, a clear understanding of the functional requirements for each individual component is required, and various important criteria or attributes need to be considered.

Researchers have focused on suppliers' selection problem since 1960's. Benton and Krajewski (1990) conclude that selection o poor vendors could lead to significant backlog and shortage in the quality o products delivered to customers (Noarul Haq and Kannan, 2006). Supplier selection decisions are very complicated because various actors that must be considered in the decision-making process. Over the years a number of quantitative approaches have been applied to supplier selection problems.

The basic issue in supplier selection survey is detecting of the selection criteria. The basic criteria typically utilized for this purpose are pricing structure, delivery (timeliness and costs), product quality, and service (personnel, facilities, research and development, capability, etc.; Soukup, 1987). The criteria typically are characterized with complexity, elusiveness, and uncertainty in nature. Ho et al. (2010) stated that supplier evaluation and selection problem has been studied extensively in the three last decades. Selecting of appropriate suppliers is a challenging issue because it complex, elusive, and uncertainty concept that is difficult to determine. Various decision making approaches have been proposed to tackle the problem. The performance of potential suppliers is evaluated against multiple criteria rather than considering a single factor-cost. Many researchers pointed out that the numbers and types of criteria totally depend on the corporate policy, objectives and strategy. The most popular criterion among hundreds of proposed ones is quality, followed by delivery, price/cost, manufacturing capability, service, management, technology, research and development, finance, flexibility, reputation, relationship, risk, and safety and environment (Ho et al., 2010; Dickson, 1966).

The main steps of problem solution are as follows: determine aim and scope $\rightarrow$ generate criteria set $\rightarrow$ generate set of alternatives $\rightarrow$ determine criteria weights $\rightarrow$ determine criteria scores $\rightarrow$ selection of aggregation model $\rightarrow$ evaluation, priority setting and improving decisions $\rightarrow$ implementing selection.

By interviewing and surveying purchase managers of firm, 6 criteria were identified for supplier selection (Table 1). A set of experiments were performed to develop and evaluate an empirical methodology to convert ordinal criteria rankings from several DMs into aggregate criteria weights, The experts sample was composed of 27 experts from different fields of stakeholders. The effects of the different decision makers on the aggregate weights were found to be insignificant at significance level $\alpha=0.05$. The importance weights of criteria are presented in Table 1 .

Linguistic variables for grey weighting criteria are shown in Table 2. 
Table 1

The criteria for evaluation of raw materials potential suppliers' selection

\begin{tabular}{llllll}
\hline & Criteria & $\begin{array}{l}\text { Measure } \\
\text { units }\end{array}$ & Opt. & \multicolumn{2}{l}{ Weight } \\
\cline { 5 - 6 } & & & & $\alpha$ & $\gamma$ \\
$x_{1}^{*}$ & Delivery price & $10^{3} € / \mathrm{m}^{3}$ & $\min$ & 0.195 & 0.210 \\
$x_{2}$ & Financial position & Points & $\max$ & 0.195 & 0.195 \\
$x_{3}$ & Performance & Points & $\max$ & 0.054 & 0.132 \\
$x_{4}$ & Standards and relevant certificates & Points & $\max$ & 0.132 & 0.195 \\
$x_{5}$ & Production specifications & Points & $\max$ & 0.171 & 0.210 \\
$x_{6}$ & Commercial strength & Points & $\max$ & 0.117 & 0.195 \\
\hline
\end{tabular}

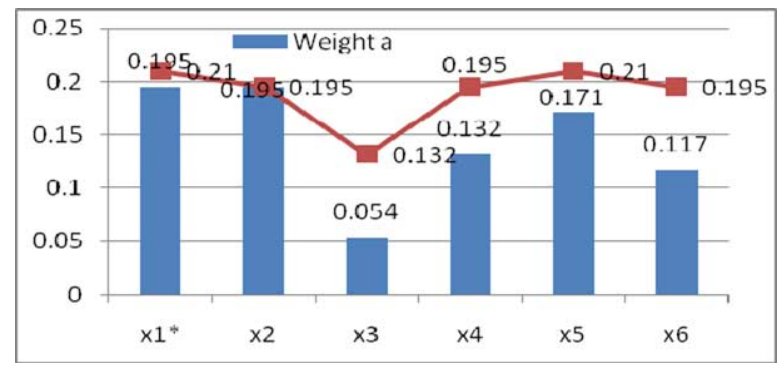

Fig. 1. Graphic representation of criteria weights in terms of $\alpha$ and $\gamma$ scores.

Table 2

The linguistic variables or the ratings

\begin{tabular}{lll}
\hline Linguistic variables & \multicolumn{2}{l}{ Grey numbers } \\
\cline { 2 - 3 } & $\alpha$ & $\gamma$ \\
\hline Very low (VL) & 0.00 & 0.20 \\
Low (L) & 0.10 & 0.30 \\
Medium low (ML) & 0.20 & 0.40 \\
Medium (M) & 0.35 & 0.65 \\
Medium high (MH) & 0.60 & 0.80 \\
High (H) & 0.70 & 0.90 \\
Very high (VH) & 0.80 & 1.00 \\
\hline
\end{tabular}

The four of possible alternatives of suppliers under consideration $A_{i}(i=\overline{1,5})$ comparing against 6 criteria are presented in Table 3. Solution process and ranking of alternatives is presented in Tables $4-6$. 
Table 3

Initial grey decision making matrix

\begin{tabular}{|c|c|c|c|c|c|c|c|c|c|c|c|c|}
\hline \multirow[t]{2}{*}{ Alt. } & \multicolumn{12}{|c|}{ Criteria } \\
\hline & $\otimes x_{1}^{*}$ & & $\otimes x_{2}$ & & $\otimes x_{3}$ & & $\otimes x_{4}$ & & $\otimes x_{5}$ & & $\otimes x_{6}$ & \\
\hline \multirow[t]{2}{*}{ Opt. } & $\min$ & & $\max$ & & $\max$ & & $\max$ & & $\max$ & & $\max$ & \\
\hline & $\alpha$ & $\gamma$ & $\alpha$ & $\gamma$ & $\alpha$ & $\gamma$ & $\alpha$ & $\gamma$ & $\alpha$ & $\gamma$ & $\alpha$ & $\gamma$ \\
\hline$w$ & 0.195 & 0.210 & 0.195 & 0.195 & 0.054 & 0.132 & 0.132 & 0.195 & 0.171 & 0.210 & 0.117 & 0.195 \\
\hline$A_{0}$ & 0.541 & 0.541 & 1.000 & 1.000 & 1.000 & 1.000 & 1.000 & 1.000 & 1.000 & 1.000 & 1.000 & 1.000 \\
\hline$A_{1}$ & 0.591 & 0.882 & 0.470 & 0.600 & 0.663 & 0.810 & 0.430 & 0.750 & 0.650 & 0.860 & 0.315 & 0.615 \\
\hline$A_{2}$ & 0.544 & 0.673 & 0.750 & 0.960 & 0.512 & 0.740 & 0.340 & 0.550 & 0.660 & 0.820 & 0.555 & 0.975 \\
\hline$A_{3}$ & 0.541 & 0.831 & 0.550 & 0.780 & 0.659 & 0.830 & 0.550 & 0.860 & 0.830 & 0.930 & 0.375 & 0.690 \\
\hline$A_{4}$ & 0.706 & 1.102 & 0.670 & 0.900 & 0.709 & 0.920 & 0.320 & 0.670 & 0.720 & 0.960 & 0.405 & 0.735 \\
\hline
\end{tabular}

Table 4

Changed-initial grey decision making matrix

\begin{tabular}{|c|c|c|c|c|c|c|c|c|c|c|c|c|}
\hline \multirow{4}{*}{ Opt. } & \multicolumn{12}{|c|}{ Criteria } \\
\hline & \multicolumn{2}{|l|}{$\otimes x_{1}$} & \multicolumn{2}{|l|}{$\otimes x_{2}$} & \multicolumn{2}{|l|}{$\otimes x_{3}$} & \multicolumn{2}{|l|}{$\otimes x_{4}$} & \multicolumn{2}{|l|}{$\otimes x_{5}$} & \multicolumn{2}{|l|}{$\otimes x_{6}$} \\
\hline & \multicolumn{2}{|l|}{$\overline{\max }$} & \multicolumn{2}{|l|}{$\max$} & \multicolumn{2}{|l|}{$\max$} & \multicolumn{2}{|l|}{$\max$} & \multicolumn{2}{|l|}{$\max$} & \multicolumn{2}{|l|}{$\max$} \\
\hline & $\bar{\alpha}$ & $\gamma$ & $\bar{\alpha}$ & $\gamma$ & $\bar{\alpha}$ & $\gamma$ & $\bar{\alpha}$ & $\gamma$ & $\bar{\alpha}$ & $\gamma$ & $\bar{\alpha}$ & $\gamma$ \\
\hline$w$ & 0.195 & 0.210 & 0.195 & 0.195 & 0.054 & 0.132 & 0.132 & 0.195 & 0.171 & 0.210 & 0.117 & 0.195 \\
\hline$A_{0}$ & 1.848 & 1.848 & 1.000 & 1.000 & 1.000 & 1.000 & 1.000 & 1.000 & 1.000 & 1.000 & 1.000 & 1.000 \\
\hline$A_{1}$ & 1.134 & 1.692 & 0.470 & 0.600 & 0.663 & 0.810 & 0.430 & 0.750 & 0.650 & 0.960 & 0.315 & 0.615 \\
\hline$A_{2}$ & 1.486 & 1.838 & 0.750 & 1.260 & 0.512 & 0.540 & 0.340 & 0.550 & 0.660 & 0.960 & 0.555 & 0.975 \\
\hline$A_{3}$ & 1.203 & 1.848 & 0.550 & 0.780 & 0.659 & 0.930 & 0.550 & 0.860 & 0.830 & 1.320 & 0.375 & 0.690 \\
\hline$A_{4}$ & 0.907 & 1.416 & 0.670 & 0.900 & 0.709 & 1.020 & 0.320 & 0.670 & 0.720 & 0.960 & 0.405 & 0.735 \\
\hline$\sum$ & 6.579 & 8.644 & 3.440 & 4.540 & 3.543 & 4.300 & 2.640 & 3.830 & 3.860 & 5.200 & 2.650 & 4.015 \\
\hline
\end{tabular}

\section{The Results of Multiple Criteria Analysis}

The criteria, whose preferable values are minima, are changed (formula 4, Table 4), The initial values of criteria were recalculated by applying normalization (formulae 20 and 21 ), That way the discrepancy between the different dimensions of the optimal values was eliminated, Normalized decision-making matrix (Table 5) was processed applying the ARAS-G method (formulae 11-18).

The solution results are presented in Table 6. The most reasonable alternative according to calculation results is second $\left(A_{3}\right)$. The priority order of the investigated alternatives can be represented as (Fig. 3). 


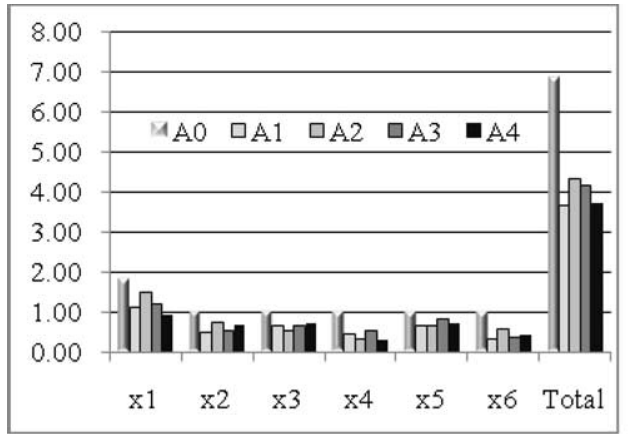

$\alpha$ scores

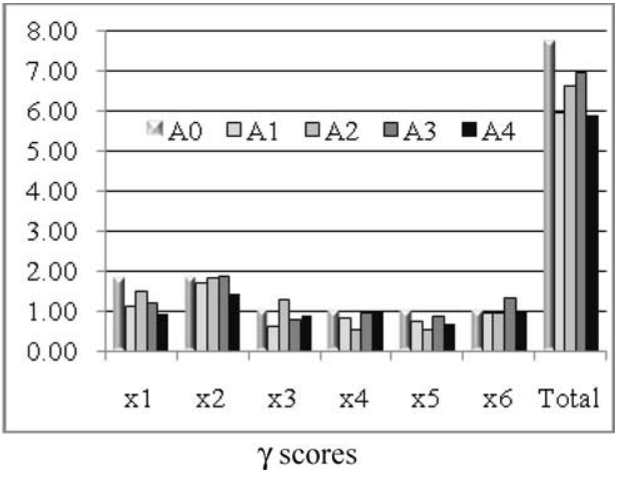

$\gamma$ scores

Fig. 2. Graphic representation of alternatives in terms of $\alpha$ and $\gamma$ scores of criteria.

Table 5

Normalised grey decision making matrix

\begin{tabular}{|c|c|c|c|c|c|c|c|c|c|c|c|c|}
\hline \multirow{3}{*}{ Opt. } & \multicolumn{2}{|l|}{$\otimes \bar{x}_{1}$} & \multicolumn{2}{|l|}{$\otimes \bar{x}_{2}$} & \multicolumn{2}{|l|}{$\otimes \bar{x}_{3}$} & \multicolumn{2}{|l|}{$\otimes \bar{x}_{4}$} & \multicolumn{2}{|l|}{$\otimes \bar{x}_{5}$} & \multicolumn{2}{|l|}{$\otimes \bar{x}_{6}$} \\
\hline & $\overline{\max }$ & & $\max$ & & $\max$ & & $\max$ & & $\max$ & & $\max$ & \\
\hline & $\alpha$ & $\gamma$ & $\alpha$ & $\gamma$ & $\alpha$ & $\gamma$ & $\alpha$ & $\gamma$ & $\alpha$ & $\gamma$ & $\alpha$ & $\gamma$ \\
\hline$w$ & 0.195 & 0.210 & 0.195 & 0.195 & 0.054 & 0.132 & 0.132 & 0.195 & 0.171 & 0.210 & 0.117 & 0.195 \\
\hline$A_{0}$ & 0.214 & 0.281 & 0.220 & 0.291 & 0.233 & 0.282 & 0.261 & 0.379 & 0.192 & 0.259 & 0.249 & 0.377 \\
\hline$A_{1}$ & 0.131 & 0.257 & 0.104 & 0.174 & 0.154 & 0.229 & 0.112 & 0.284 & 0.125 & 0.249 & 0.078 & 0.232 \\
\hline$A_{2}$ & 0.172 & 0.279 & 0.165 & 0.366 & 0.119 & 0.152 & 0.089 & 0.208 & 0.127 & 0.249 & 0.138 & 0.368 \\
\hline$A_{3}$ & 0.139 & 0.281 & 0.121 & 0.227 & 0.153 & 0.262 & 0.144 & 0.326 & 0.160 & 0.342 & 0.093 & 0.260 \\
\hline$A_{4}$ & 0.105 & 0.215 & 0.148 & 0.262 & 0.165 & 0.288 & 0.084 & 0.254 & 0.138 & 0.249 & 0.101 & 0.277 \\
\hline
\end{tabular}

Table 6

Normalised-weighted grey decision making matrix and solution results

\begin{tabular}{lllllllllllllll}
\hline & $\otimes \hat{x}_{1}$ & & $\otimes \hat{x}_{2}$ & & $\otimes \hat{x}_{3}$ & & $\otimes \hat{x}_{4}$ & \multicolumn{3}{c}{$\otimes \hat{x}_{5}$} & \multicolumn{3}{c}{$\otimes \hat{x}_{6}$} \\
\hline$A_{0}$ & 0.042 & 0.059 & 0.043 & 0.057 & 0.013 & 0.037 & 0.034 & 0.074 & 0.033 & 0.054 & 0.029 & 0.074 \\
$A_{1}$ & 0.026 & 0.054 & 0.020 & 0.034 & 0.008 & 0.030 & 0.015 & 0.055 & 0.021 & 0.052 & 0.009 & 0.045 \\
$A_{2}$ & 0.034 & 0.059 & 0.032 & 0.071 & 0.006 & 0.020 & 0.012 & 0.041 & 0.022 & 0.052 & 0.016 & 0.072 \\
$A_{3}$ & 0.027 & 0.059 & 0.024 & 0.044 & 0.008 & 0.035 & 0.019 & 0.064 & 0.027 & 0.072 & 0.011 & 0.051 \\
$A_{4}$ & 0.020 & 0.045 & 0.029 & 0.051 & 0.009 & 0.038 & 0.011 & 0.049 & 0.024 & 0.052 & 0.012 & 0.054
\end{tabular}

\begin{tabular}{llll}
\hline & $\otimes S$ & $S$ & $K$ \\
\hline$A_{0}$ & 0.548 & 0.274 & 1 \\
$A_{1}$ & 0.371 & 0.185 & 0.676 \\
$A_{2}$ & 0.437 & 0.218 & 0.796 \\
$A_{3}$ & 0.440 & 0.220 & 0.803 \\
$A_{4}$ & 0.395 & 0.197 & 0.720
\end{tabular}$\quad$ Alternatives ranks as follows: $A_{3} \succ A_{2} \succ A_{4} \succ A_{1}$




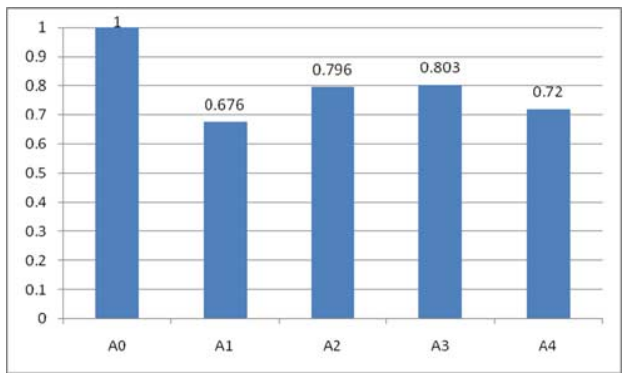

Fig. 3. Comparison of suppliers' alternatives performance level.

It means that the best alternative is third, and the worst alternative is the first. It can be stated that the alternative 3 is only $80 \%$ of optimal alternative performance level, and the performance of the worst alternative 1 is only $68 \%$.

According to the given data on the criteria describing the alternatives, rational solutions about supplier's selection can be made. With an illustrative example: selection of a potential supplier the proposed methodology is validated, It is found that there are six main criteria which must to be considered: Delivery Price ( $\gamma$ weight equals to 0.210$)$, Production Specifications ( $\gamma$ weight equals to 0.210$)$, Financial Position $(\gamma$ weight equals to 0.195), Standards and Relevant Certificates ( $\gamma$ weight equals to 0.195), Commercial Strength ( $\gamma$ weight equals to 0.195$)$, and the Performance ( $\gamma$ weight equals to 0.132 ).

\section{Conclusions}

Traditional optimization, statistical and econometric analysis approaches used within the engineering context are often based on the assumption that the considered problem is well formulated and decision-makers usually consider the existence of a single objective, evaluation criterion or point of view that underlies the conducted analysis, In such a case the solution of engineering problems is easy to obtain.

But in reality, the modelling of engineering problems is based on a different kind of logic taking into consideration the existence of multiple criteria, the conflicting aims of decision maker, the complex, subjective and different nature of the evaluation process, and the participation of several decision makers.

In this paper it is supposed to deal with grey data to help the model to be very applicable due to lack of certainty and crisp data in real word situations especially about qualitative variables.

In this paper is developed new additive ratio analysis method with grey criteria scores - ARAS-G. Researchers and stakeholders found a way to evaluate and rank alternatives by applying grey values, and to compare scores of alternatives with the ideal possible alternative.

An example of a supplier selection problem was used to illustrate the proposed approach. The experimental result shows that the proposed approach is reliable and reasonable. Weights results show that stakeholders are more concern about the delivery price 
and the production specification than the commercial strength and the performance of suppliers.

In conclusion, ARAS-G method has a promising future in the decision making field, because he offers a highly methodological basis for decision support.

\section{References}

Benton, W.C., Krajevski, L. (1990). Vendor performance and alternative manufacturing environment. Decision Science, 21, 403-415.

Berkeley, D., Humphreys, P., Larichev, O., Moshkovich, H. (1991). Aiding strategic decision making: Derivation and development of ASTRIDA. In: Vecsenyi, Y. and Sol, H. (Eds.), Environment for Supporting Decision Processes, North-Holland, Amsterdam.

Bous, G., Fortemps, P., Glineur, F., Pirlot, M. (2010). ACUTA: A novel method for eliciting additive value functions on the basis of holistic preference statements. European Journal of Operational Research, 206, 435-444.

Brans, J.P., Mareschal, B., Vincke, P. (1984). PROMETHEE: A new family of outranking methods in multicriteria analysis. In: Brans, J.P. (Ed.), IFORS 84, North-Holland, Amsterdam, pp. 477-490.

Chen, M.-F., Tzeng, G.-H. (2004). Combining grey relation and TOPSIS concepts for selecting an expatriate host country. Mathematical and Computer Modelling, 40(13), 1473-1490.

Deng, J. 1982. Control problems and Grey systems. Systems and Control Letters, 5(2), 288-294.

Dickson, G.W. (1966). An analysis of supplier selection system and decision. Journal of Purchasing, 2(1), 5-17.

Ginevičius, R. (2008). Normalization of quantities of various dimensions. Journal of Business Economics and Management, 9(1), 79-86.

Ginevicius, R., Podvezko, V., Raslanas, S. (2008). Evaluating the alternative solutions of wall insulation by multicriteria methods. Journal of Civil Engineering and Management, 14(4), 217-226.

Grigoroudis, E., Siskos, Y. (2002). Preference disaggregation for measuring and analysing customer satisfaction: the MUSA method. European Journal of Operational Research, 143(1), 148-170.

Ho, W., Xu, X., Dey, P.K. (2010). Multi-criteria decision making approaches for supplier evaluation and selection: a literature review. European Journal of Operational Research, 202(1), 16-24.

Hwang, C.L., Yoon, K. (1981). Multiple attribute decision making. In: Lecture Notes in Economic and Mathemathical Systems, Vol. 186, Springer, Berlin.

Jacquet-Lagreze, E., Siskos, J. (1982). Assessing a set of additive utility functions for multicriteria decisionmaking, the UTA method. European Journal of Operational Research, 10(2), 151-164.

Kalibatas, D., Turskis, Z. (2008). Multicriteria evaluation of inner climate by using MOORA method. Information technology and control, 37(1), 79-83.

Kapliński, O. (2008). Usefulness and credibility of scoring methods in construction industry. Journal of Civil Engineering and Management, 14(1), 21-28.

Kersuliene, V., Zavadskas, E.K., Turskis, Z. (2010). Selection of rational dispute resolution method by applying new step-wise weight assessment ratio analysis (SWARA). Journal of Business Economics and Management, 11(2), 243-258.

Li, G.-D., Yamaguchi, D., Nagai, M. (2007). A grey-based decision-making approach to the supplier selection problem. Mathematical and Computer Modelling, 46(3-4), 573-581.

MacCrimon, K.R. (1968). Decision Marking Among Multiple-Attribute Alternatives: A Survey and Consolidated Approach. RAND Memorandum, RM-4823-ARPA. The Rand Corporation, Santa Monica, CA.

Medineckiene, M., Turskis, Z., Zavadskas, E.K. (2010). Sustainable construction taking into account the building impact on the environment. Journal of Environmental Engineering and Landscape Management, 18(2), 118-127.

Noarul Haq, A., Kannan, G. (2006). Fuzzy analytical hierarchy process for evaluating and selecting a vendor in a supply chain model. International Journal of Advanced Manufactoring Technolgy, 29, 826-835.

Noarul Haq, A., Kannan, G.A. (2007). Hybrid normalised multi criteria decision making for the vendor selection in a supply chain model. International Journal of Management and Decision Making, 8(5-6), 601-622. 
Roubens, M. (1982). Preference relations on actions and criteria in multi-criteria decision making. European Journal of Operational Research, 10(1), 51-55.

Roy, B. (1990). Decision-aid and decision-making. European Journal of Operational Research, 45, 324-331.

Saaty, T.L. (1977). A scaling method for priorities in hierarchical structures. Journal of Mathematical Psychology, 15, 234-281.

Sivilevičius, H., Zavadskas, E.K., Turskis, Z. (2008). Quality attributes and complex assessment methodology of the asphalt mixing plant. The Baltic Journal of Road and Bridge Engineering, 3(3), 161-166.

Soukup, W. (1987). Supplier selection strategies. Journal of Purchasing and Materials Management, 23(2), $7-12$.

Srinivasan, V., Shocker, A.D. (1973). Linear programming techniques for multidimensional analysis of privileged. Psychometrika, 38, 337-369.

Tupenaite, L., Zavadskas, E.K., Kaklauskas, A., Turskis, Z., Seniut, M. (2010). Multiple criteria assessment of alternatives for built and human environment renovation. Journal of Civil Engineering and Management, 16(2), 257-266.

Turskis, Z. (2008). Multi-attribute contractors ranking method by applying ordering of feasible alternatives of solutions in terms of preferability technique. Technological and Economic Development of Economy, 14(2), 224-239.

Turskis, Z., Zavadskas, E.K., Peldschus, F. (2009). Multi-criteria optimization system for decision making in construction design and management. Inzinerine Ekonomika - Engineering Economics (1), 7-17.

Vansnick, J.C. (1986). On the problem of weights in multiple criteria decision making (the noncompensatory approach). European Journal of Operational Research, 24, 288-294.

Wu, H.-H. (2006). Applying grey model to prioritise technical measures in quality unction development. International Journal of Advanced Manufactoring Technolgy, 29, 1278-1283.

Zavadskas, E.K., Kaklauskas, A. (1996). Determination of an efficient contractor by using the new method of multicriteria assessment. In: Langford, D.A., Retik, A. (Eds.) International Symposium for "The Organisation and Management of Construction, Shaping Theory and Practice, Vol. 2, Managing the Construction Project and Managing Risk". CIB W/65. E. \& F.N. Spon, London, pp. 94-104.

Zavadskas, E.K., Turskis, Z. (2008). A new logarithmic normalization method in games theory. Informatica, 19(2), 303-314.

Zavadskas, E.K., Turskis, Z. (2010). A new additive ratio assessment (ARAS) method in multicriteria decisionmaking. Technological and Economic Development of Economy, 16(2), 159-172.

Zavadskas, E.K., Turskis, Z., Tamosaitiene, J. (2008a). Contractor selection of construction in a competitive environment. Journal of Business Economics and Management, 9(3), 181-187.

Zavadskas, E.K., Liias, R., Turskis, Z. (2008b). Multi-attribute decision-making methods for assessment of quality in bridges and road construction: state-of-the-art surveys. The Baltic Journal of Road and Bridge Engineering, 3(3), 152-160.

Zavadskas, E.K., Kaklauskas, A., Turskis, Z., Tamošaitienè, J. (2008c). Selection of the effective dwelling house walls by applying attributes values determined at intervals. Journal of Civil Engineering and Management, 14(2), 85-93.

Zavadskas, E.K., Turskis, Z., Tamošaitienė, J., Marina, V. (2008d). Multicriteria selection of project managers by applying grey criteria. Technological and Economic Development of Economy, 14(4), 462-477.

Zavadskas, E.K., Kaklauskas, A., Turskis, Z., Kalibatas, D. (2009a). An approach to multi-attribute assessment of indoor environment before and after refurbishment of dwellings. Journal of Environmental Engineering and Landscape Management, 17(1), 5-11.

Zavadskas, E.K., Kaklauskas, A., Turskis, Z., Tamosaitiene, J. (2009b). Multi-attribute decision-making model by applying grey numbers, Informatica, 20(2), 305-320.

Zavadskas, E.K., Turskis, Z., Vilutiene, T. (2010a). Multiple criteria analysis of foundation instalment alternatives by applying additive ratio assessment (ARAS) method. Archives of Civil and Mechanical Engineering, 10(3), 123-141.

Zavadskas, E.K., Vilutiene, T., Turskis, Z., Tamosaitiene, J. (2010b). Contractor selection for construction works by applying SAW-G and TOPSIS grey techniques. Journal of Business Economics and Management, 11(1), $34-55$.

Zimmermann, H.-J. (2000). An application-oriented view of modelling uncertainty. European Journal of Operational Research, 122(2), 190-198. 
Z. Turskis has a $\mathrm{PhD}$ and is a chief research worker at Laboratory of Construction Technology and Management in Vilnius Gediminas Technical University, Lithuania, His research interests include building technology and management, decision-making theory, computer-aided automation in design and expert systems, and he is the author of 69 research papers.

E.K. Zavadskas is principal vice-rector of Vilnius Gediminas Technical University, and head of the Department of Construction Technology and Management at Vilnius Gediminas Technical University, Vilnius, Lithuania. He has a PhD, in building structures (1973) and DrSc (1987) in building technology and management. He is a member of the Lithuanian and several foreign Academies of Sciences. He is Doctore Honoris Causa at Poznan, Saint-Petersburg, and Kiev universities. He is a member of international organisations and has been a member of steering and programme committees at many international conferences. E.K. Zavadskas is a member of editorial boards of several research journals. He is author and co-author of more than 400 papers and a number of monographs. Research interests are: building technology and management, decision-making theory, automation in design and decision support systems.

\title{
Naujas daugiakriterinės analizès metodas: pilkojo suminio santykinio vertinimo (ARAS-G) metodas
}

\author{
Zenonas TURSKIS, Edmundas Kazimieras ZAVADSKAS
}

Straipsnyje pateikiamas proceso modelis tinkamausiam tiekejjui iš potencialiu tiekeju aibès atrinkti, kuris tenkintų suinteresuotujų grupių interesus. Pasirinkimas yra grindžiamas tokiais kriterijais: pristatymo kaina, finansiné tiekejo padètis, gamybos specifikaciju, standartų ir reikiamu sertifikatų tenkinimas, prekybinė galia ir tiekéjo patrauklumas ir kt. Vertinimo kriterijai ir ju svarba yra pasirinkti atsižvelgiant ị suinteresuotujų šalimių interesus ir tikslus. Problemos sprendimui buvo sukurtas ir pateiktas naujas daugiakriterinės analizės metodas: Pilkojo suminio santykinio vertinimo (ARAS-G) metodas. Siūlomas metodas galètų būti taikomas pagrịsti tvarios plètros alternatyvu vertinima, poveikio aplinkai atranką, sprendžiant staybos konstrukcijụ, technologijos, investicijų ir t.t. parinkimo uždavinius. 